\title{
Ontology rules application for efficient career choice
}

\author{
Elena Startseva ${ }^{1}$, Andrey Grimaylo ${ }^{2}$, Liliya Chernyahovskaya ${ }^{3}$, Fernando Llopis \\ Pascual $^{4}$ \\ ${ }^{1}$ Department of Natural Language and Information Systems, University of Alicante, Spain, \\ ${ }^{2}$ Department of Translation and Interpreting, University of Alicante, Spain, ${ }^{3}$ Department of \\ Informatics and Robotics, Ufa State Aviation Technical University, Russia, ${ }^{4}$ Department of \\ Natural Language and Information Systems, University of Alicante, Spain.
}

\begin{abstract}
The aim of this work is to help university applicants in their transition phase from high-school to tertiary education starting with their first life-long decision concerning their choice of the field of study.

The construction of the decision support system has evolved into an ontologybased model. The model, as well as the decision making rules, have been formulated based on the research study of the cohort of 119230 students of the University of Alicante between 2010 and 2018.
\end{abstract}

The educational and psychological processes have been studied in order to identify the pivot moments and the factors that may lead to an adequate decision making or to an objectively wrong decision which eventually ends up in a drop-out of studies.

Analysing the existing methods of occupational and educational choice assistance, the method of John L. Holland on "A Psychological Classification of Occupations" has been selected as the most viable and convenient for this purpose. The Holland Codes have been adopted as a lingua franca of this ontology-based model.

As a result, the ontology-based decision support system provides assistance in decision making using the Holland Code terminology and practically unlimited complexity of the object and data properties of and ontological presentation of knowledge.

Keywords: ontology-based decision support system; occupational and educational choice; Holland Code. 


\section{Introduction}

Student's natural learning motivation has been an objective of many educational research works. Being properly and timely recognized this motivation makes it possible for a young person to adequately and independently make the best educational choice which will have a life-long effect. The willingness to study, the volume and the quality of the information taken, occupational satisfaction, a life-long success and personal adaptation of each member of the modern society depend on those decisions.

For that purpose, the following assignments have been accomplished: statistical analysis of the first year performance for a cohort of 11923 students of the University of Alicante. We analysed in a longitudinal sample spanning from 2010/11 to 2017/18.

An ontology has been developed in order to rationalize, organize and automate the processes, procedures of the decision support system, based on the rules within the semantic net context notions of the study area in question.

\section{Current state of affairs}

At the age of 15-16, when opting between existing high-school educational study programmes (Vidal I. M., 2014) young people have to face their first life defining decisions. Having taken one of the educational options the high-school students limit themselves in terms of their future careers (Startseva E.B., 2017).

Spanish high school students specialize in three study programmes (Sanchez, 2014): natural science, social studies, arts and humanitarian studies which are to prepare the high school leavers for enrolment in university also in three different fields of study correspondingly.

The diagram below (Fig. 1) reveals that although the three main high-school study programmes are equally represented between high school leavers, $64 \%$ of the university entrants (Fig. 2) prefer social studies and economics rather than anything else, and only $8 \%$ seem to seek a humanitarian or languages careers. Moreover, this proportion changes even after the enrolment process is over. 


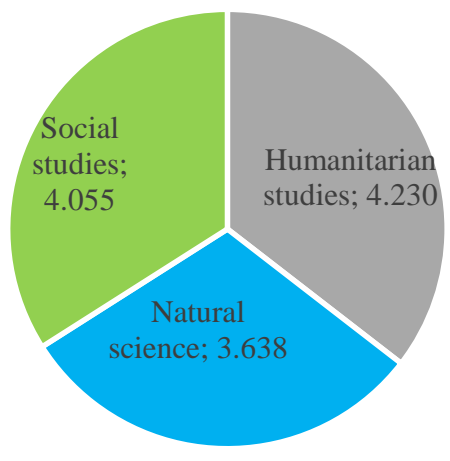

Fig.1. High School study programmes

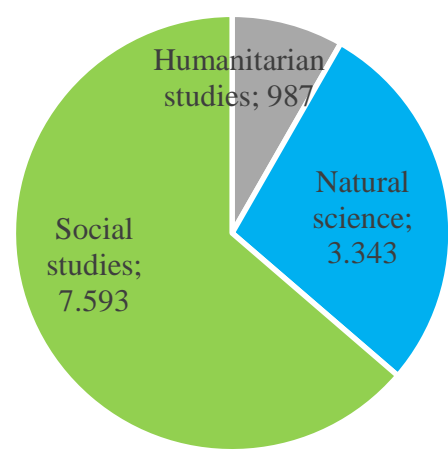

Fig.2. University fields of study

Similarly, in the US "up to 80 per cent of matriculants enter college undecided on a major and up to 50 per cent change majors at some point during their enrolment” (Ronan, 2005).

While the number of students has been rising, so has the proportion who fail to come back for a second year. In all, more than a million US students a year quit college (Marcus, 2018). High dropout rates and overly extended studies among undergraduate students represent an increasing challenge to the modern society. "In America 40 per cent of college students fail to graduate with four-year degrees within six years of enrolling. Drop-out rates across the developed world average around 30 per cent“ (The Economist, 2018). A third of Spanish undergraduate students do not complete their degree in 4 years or simply dropout (Ministerio de Educación, Cultura y Deporte, 2016).

These figures raise a very important question of why many former high-school students eventually transferred to a field of study that was very different from their high-school study programme, quit college or overly extend the time to graduate and whether half of the university entrants are not pleased with their high school choice or they are unsure about their next career oriented step. In other words, they have either made an erroneous choice while studying at high school or are making a mistake choosing a wrong university career, or both.

In 2017/2018, Spanish expenditure on education reached $€ 51.3$ billion of which 20 per cent ( $€ 10.26$ billion) was directly invested in the higher education, and nearly $€ 530$ million was awarded for scholarships, increasing expenditure to nearly €11 billion. (Ministerio de Educación y Formación profesional). With a 1/3 of all university entrants eventually finding themselves dissatisfied with their field of study and considering the dropout option, this results in an annual cost of over $€ 3$ billion to the public purse. (Vidal M. , 2017)

The number of undecided students varies across institutions and sources but the volume it represents highlights the large impact and importance of understanding and assisting the 
undecided (Emily Bullock-Yowell, 2014) as well as those who believe that they have already made their commitment to a major and a potential career.

At the same time being a student is not a solution in itself. Students have little understanding of the skills and degrees that will increase their employability (Bersin, 2013). According to some studies, up to 47 percent of U.S. jobs and over 70 per cent of those in India were rated as highly likely to become computerized in the next 10-20 years. Such qualifications as an accountant will be of little benefit for the individual employee, because - over time - there is a 98 per cent probability that the work of an accountant can be done by intelligent software (Alfons Botthof, 2015), in the worst case scenario it may happen even before the student has passed all ECTS credits.

Hence, research in the area of careers guidance is crucial for all stakeholders especially young people who need to be guided as to the important aspects to consider before choosing their field of study at University. This guidance shall form a part of the "strategic framework for European cooperation in education and training in order to respond to the challenges of the modern world, to better provide the means for all citizens to realize their potentials, as well as ensure sustainable economic prosperity and employability" (European Commission, 2018).

For example, the quantitative analysis of the first year University performance for cohort of more than 11000 university entrants has proved that those with the natural science high school background are better off (82\% of the ECTS credits passed) in all university fields of study. While those majored in humanitarian and social studies showed $72,3 \%$ and $71,4 \%$ of the ECTS credits passed correspondingly (Fig.3).

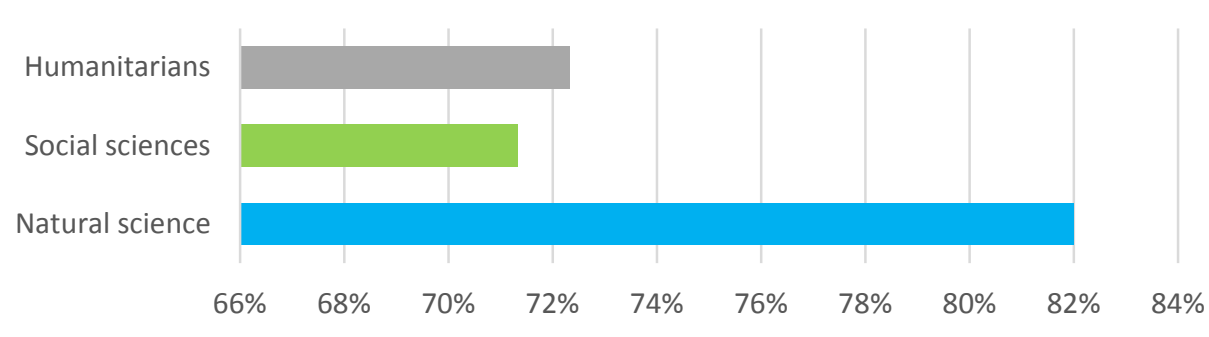

Fig. 3. End of year pass rate of the ECTS credits for each high school study programme

The educational and psychological processes have been studied in order to identify the pivot moments and the factors that may lead to an adequate decision making or to an objectively wrong decision which eventually ends up in a drop-out of studies. 


\section{Ontology description}

The proposed ontology-based decision support system (DSS), apart from the high-school performance factors (which are at the moment the generally accepted key indicators in choosing the field of study), make use of large spectrum of knowledge i.e. expert assessment of labor market perspective, strategic planning requirements, occupational psycology (Holland Occupation Test (Holland Code Career Test, 2017)) that focuses on career and vocational choice by grouping people on the basis of their suitability for different categories of occupations, the Position Classification Inventory (PCI) (Gottfredson, 1991) which enables to use the Self-Directed Search results to locate and explore the degree of match between an applicant and future job, provide a structure for locating future career possibilities, the Multiple Intelligences theory which focuses on strengths or intelligences that can be interpreted as learning styles, information on the applicant's individual characteristics based on the human design classification (Parkyn, 2010) (logical and consistent system which the authors find quite useful to apply in order to prove validity of other theories and methods).

The ontological model DSS has been applied for data and knowledge analysis to provide integrity and consistency and to be used for elaboration of the DSS rules. Those rules shall provide an applicant with an answer as to which major to choose, the study prospective in general using the input of the individual data mentioned before. The authors believe that this information will encourage each student to study the chosen major and also duly inform the applicant about possible riskes implied by the choice taken.

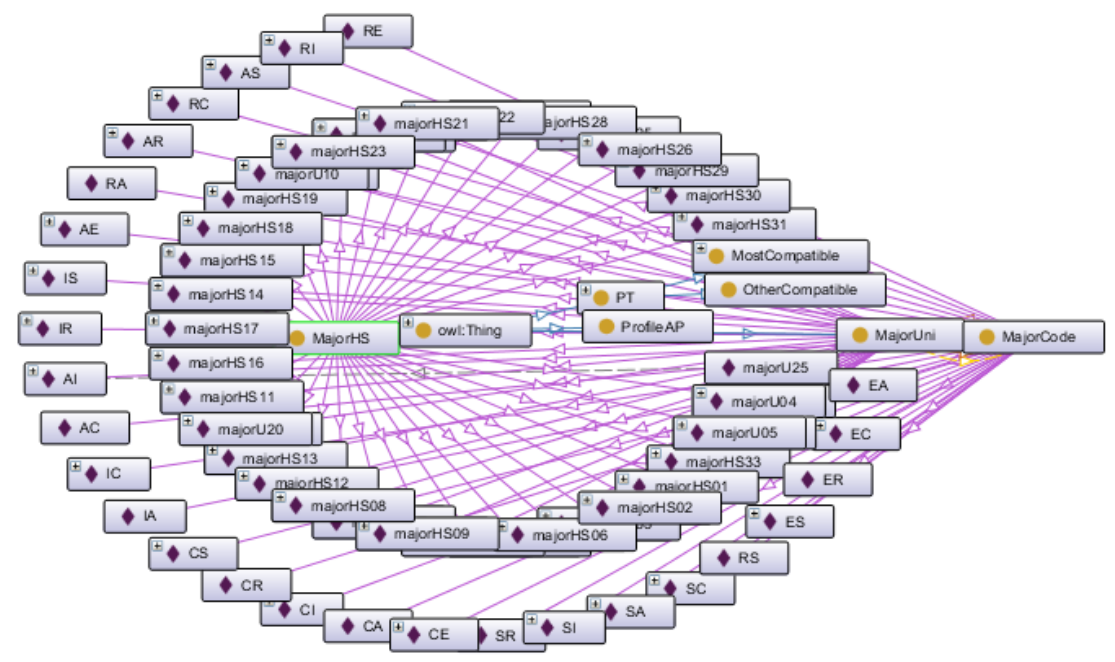

Fig. 4. OntoGraf with the class samples and objects 
The contruction phase of the ontology-based DSS is presented in Fig.4. The main characteristic of the proposed system shall be the following: its ability to identify the applicants' architypes: to recognize an educational behavioural pattern and, more importantly, capabilities and inclinations together with the ability to spot the congruent professional areas. Instead of saying that "learning can be characterized as the procedure of obtaining knowledge or aptitudes (Shaimaa Nafea, 2016) we can add that with the help of the ontology-based DSS learning starts with the procedure of self-recognition, use of the natural learning patterns, identification and encouragement of natural professional inclination. The core idea of the system is that every person is individually gifted, it treats the capabilities (competencies) as the possibility for a person to significantly contribute into the social development (Gvozdev V.E., 2014).

The Holland Codes have been adopted as a lingua franca of this ontology-based model. At the initial stage the proposed ontology-based decision support system shall assist its users (high-school student and university applicants) to identify the best choice major and take the correct learning path. This system applies productive rules in order to select an adequate field of study on an individual basis by using semantic rules and rule-based reasoning so as to detect the individually corresponding fields of study. Eventually this ontology can be applied together with other ontologies like Learning Domain Ontology and become a part of the Learning Network.

Application of all these criteria has made it possible to formulate the decision making rules for a better choice of a university major.

These rules are formulated in SWRL on the subject area ontology (Fig. 5).

\begin{tabular}{l} 
Rules: \\
\hline Rules + \\
Applicant(?x), MajorUni(?u), hasCutoffMark(?u, ?e), hasEntranceMark(?x, ?d), \\
hasEntrancePossibility(?x, ?b), greaterThan(?d, ?e) -> has_value(?b, "high") \\
Applicant(?x), MajorUni(?u), hasAMProfile(?x, ?g), hasHollandTestProfile(?u, ?a), \\
has_value(?g, "correspondent") -> hasAdequacy(?x, ?u) \\
Applicant(?x), LowChance(?lc), MajorUni(?u), corresponds(?x, ?u), enroll(?x, ?u), \\
EntranceExam(?x, ?b), hasScore_value(?b, "low") -> has_value(?ch, "false") \\
Applicant(?x), HighChance(?ch), MajorUni(?u), corresponds(?x, ?u), EntranceExam(?x, \\
?a), hasScore_value(?a, "high") -> has_value(?ch, "trie") \\
Applicant(?x), MajorUni(?u), hasAMProfile(?x, ?g), has_value(?g, "not_correspondent") \\
-> hasInadequacy(?x, ?u) \\
Applicant(?x), MajorHS(?z), MajorUni(?u), hasEntrancePossibility(?x, ?b), \\
hasStudyField(?z, ?h), hasSuccessPossibility(?x, ?c), has_value(?b, "high"), \\
has_value(?h, "Science") -> has_value(?c, "low") \\
Applicant(?x), MajorHS(?z), MajorUni(?u), hasCutOffMark(?u, ?e), hasEntranceMark(?x, \\
?d), hasEntrancePossibility(?x, ?b), hasSuccessPossibility(?x, ?c), has_value(?b, \\
"high"), lessThanOrEqual(?e, ?d) -> has_value(?c, "low") \\
Applicant(?x), MajorUni(?u), hasCutOffMark(?u, ?e), hasEntranceMark(?u, ?d), \\
hasEntrancePossibility(?x, ?b), lessThanOrEqual(?d, ?e) -> has_value(?b, "average")
\end{tabular}

Fig. 5. Examples of SWRL rules 
The obtained results of the rules application as well as dynamic monitoring of the main economic and social tendencies make it possible to adjust and update the DSS through introduction of the new rules.

This work made use of the methods and models developed under the RFBR Grant 18-0000238 "Methods and models of the intellectual decision support in innovative project management on the basis of knowledge of engineering".

\section{References}

Alfons Botthof, E. A. (2015). Zukunft der Arbeit in Industrie 4.0. Berlin: Springer Vieweg. Bersin, J. (22 de 3 de 2013). The Educational Mismatch. Chief Learning Officer, págs. 2-4.

Emily Bullock-Yowell, A. E. (2014). Decided and Undecided Students: Career Self-efficacy, Negative Thinking, and Decision-Making Difficulties. NACADA Journal, Vol. 34(No. 1).

European Commission. (2018). The European Higher Education Area in 2018: Bologna Process Implementation Report. Luxembourg: Publications Office of the European Union.

Gottfredson, G. D. (1991). Position classification inventory (PCI). Odessa: Psychological Assessment Resources.

Gvozdev V.E., C. L. (2014). Intellectually analytical collective decision support in project management. Samara: Scientific Centre RAS.

Holland Code Career Test. (2017). (TRUITY) Recuperado el 1 de 11 de 2018, de TRUITY: https://www.truity.com/test/holland-code-career-test

Marcus, J. (5 de 7 de 2018). The Hechinger Report. Recuperado el 15 de 9 de 2018, de hechingerreport.org: https://hechingerreport.org/more-high-school-grads-than-ever-aregoing-to-college-but-1-in-5-will-quit/

Ministerio de Educación, Cultura y Deporte. (2016). Estadística de Indicadores Universitarios. 2016. Madrid: Ministerio de Educación, Cultura y Deporte. Obtenido de https://www.mecd.gob.es/servicios-al-ciudadano-mecd/dms/mecd/servicios-alciudadano-mecd/estadisticas/educacion/universitaria/estadisticas/estadisticaindicadores-universitarios/nota-estadistica-indicadores-universitarios-16-03-2017.pdf: https://www.mecd.gob.es/servicios-al-ciudadano-mecd/dms/mecd/servicios-alciudadano-mecd/estadisticas/educacion/universitaria/estadisticas/estadisticaindicadores-universitarios/nota-estadistica-indicadores-universitarios-16-03-2017.pdf

Parkyn, C. (2010). Human Design : Discover the Person You Were Born to Be: A Revolutionary New System Revealing the DNA of Your True Nature. Novato: NEW WORLD LIBRARY.

Ronan, G. B. (2005). College freshmen face major dilemma: Indecision about courses of study can prove expensive. Obtenido de http://www.nbcnews.com/: http://www.nbcnews.com/id/10154383/ns/business-personal\#.XHq9Dqu_hhE

Sanchez, R. M. (4 de 2014). Secondary School Scheme accoding to LOMCE (ESQUEMA DE LA ESO SEGÚN LOMCE). Andalucia: CODAPA. 
Shaimaa Nafea, L. A. (2016). Personalized Students’ Profile Based On Ontology and Rulebased Reasoning. EAI Endorsed Transactions on e-Learning, 3(12).

Startseva E.B., G. A. (2017). Ontological analysis methods as a tool for a personal decision making process. Workshop on computer science and information technologies 19thCSIT'2017. Baden-Baden.

The Economist. (3 de 2 de 2018). Going to university is more important than ever for young people. Recuperado el 1 de 10 de 2018, de https://www.economist.com: https://www.economist.com/international/2018/02/03/going-to-university-is-moreimportant-than-ever-for-young-people

Vidal, I. M. (22 de 9 de 2014). Chose your future "Bachillerato or profesional secondary education”. Bekia y Padres, págs. 1-2.

Vidal, M. (21 de 6 de 2017). Las carreras con más salida laboral tienen mayor tasa de abandono. Recuperado el 15 de 9 de 2018, de Crónica Global: https://cronicaglobal.elespanol.com/vida/carreras-salida-laboralabandono_75294_102.html 